\title{
The Effects of Compliance and Growth Opinions on SMEs Compliance Decisions: An Empirical Evidence from Ghana
}

\author{
Eugene Oware Koranteng1, Eugene Osei-Bonsu1, Francis Ameyaw¹, Bismark Ameyaw²*, \\ Joy Korang Agyeman'2, Richmond Asirifi Dankwa ${ }^{3}$

\footnotetext{
${ }^{1}$ Faculty of Business and Management, Koforidua Technical University, Koforidua, Ghana

${ }^{2}$ School of Management and Economics, University of Electronic Science and Technology of China, Chengdu, China

${ }^{3}$ School of Public Administration, University of Electronic Science and Technology of China, Chengdu, China
} \\ Email: ^3101153683@qq.com
}

How to cite this paper: Koranteng, E.O., Osei-Bonsu, E., Ameyaw, F., Ameyaw, B., Agyeman, J.K. and Dankwa, R.A. (2017) The Effects of Compliance and Growth Opinions on SMEs Compliance Decisions: An Empirical Evidence from Ghana. Open Journal of Business and Management, $\mathbf{5}$, 230-243.

https://doi.org/10.4236/ojbm.2017.52021

Received: January 9, 2017

Accepted: April 8, 2017

Published: April 13, 2017

Copyright $\odot 2017$ by authors and Scientific Research Publishing Inc. This work is licensed under the Creative Commons Attribution International License (CC BY 4.0).

http://creativecommons.org/licenses/by/4.0/

\begin{abstract}
Generally, there has been an increase in the trend of interest of majority of people evaluating tax compliance decisions due to the fact that taxes help in funding public expenditures as well as boosting the expansion of most SME businesses. On the other hand, there has also been a sudden increase of interest in the development of Small and Medium Scale Enterprises (SMEs). In most developing and developed countries, SMEs are the spine of economic growth. Therefore, it is necessary that concentration is not only given to the generation of taxes but also the wellbeing of tax payers hence, SMEs. However, the current situation of Ghana shows an imbalance between these two major contributing factors. Due to such imbalance, the paper analyses the effects of perception and growth opinions on tax compliance decisions in Ghana. Specifically, the paper seeks to analyze respondents' subjective opinions on the growth of their businesses, how their growth opinions affect their perception on taxes and how those perceptions contributes to tax compliance. In analyzing SMEs compliance issues on taxes, a total of 840 questionnaires were submitted to registered SMEs across all the ten (10) regions of Ghana. The data was analyzed using Stata 12 and E-views 7.1 concurrently. The results of this research revealed that SMEs have negative subjective opinions on their growth thus having negative effect on their general perception towards taxes thereby posing a negative effect on SMEs compliance to taxes. The findings of the research will give an insight to the GRA (Ghana Revenue Authority) in formulating strategies on taxation and SMEs growth in an efficient and effective way.
\end{abstract}




\section{Keywords}

Taxation, Perception, Compliance, Growth, SMEs

\section{Introduction}

Globally, the economic development of most countries hinges on SMEs. According to [1], SMEs are the backbone of the world's economies. SMEs continue to attract various stakeholders in areas of research and development, training and development etc. due to their immense contribution in helping solve employment issues [2]. Generally, it can be said that SMEs contribute higher percentages of Gross Domestic Product (GDP) in most countries and also, form a higher percentage of the private sector, especially in developing countries [3]. According to [2], SMEs constitute approximately $99 \%$ of a projected 19.3 million enterprises in the European Union (EU) offering about 65 million jobs representing two-thirds of all employment opportunities in Europe. In the context of developing countries, most businesses are dominated by SMEs and employ a significant portion of the population hence helping in creating employment and improving the general standard of living of people [4]. On the other hand, taxation also plays a major role to the development and welfare of an economy. Taxation helps in the generation of income for funding public expenditures. However, the issue of taxation is a complicated one especially in developing countries. The payment of tax is inevitable. Likewise, the income and need for survival of $\mathrm{SME}_{\mathrm{S}}$ should also be considered. The Organization for Economic Cooperation and Development (OECD) issued a "Bologna Charta on SME policies" in which governments from OECD countries recognized the roles of $\mathrm{SME}_{\mathrm{S}}$ as well as recommending broad policy orientations conducive for their growth [5].

In Ghana, the contribution of private sector businesses to economic development cannot be underestimated. $40 \%$ of Ghana's Gross National Income (GNI) is generated from private businesses which are dominated by SMEs [6]. Performance of $\mathrm{SME}_{\mathrm{S}}$ in Ghana in one way or the other hasn't achieved its goal of playing significant role in the growth of the Ghanaian economy. Governments have tread tirelessly in developing policies to promote $\mathrm{SME}_{\mathrm{S}}$ development through rising incentive schemes thus allocating huge sums of money to provide technical assistance to SMEs yet this challenge remains same despite all these efforts. Ghanaians are well aware that the engine for the growth of the economy hinges solely on the private sector $\left(\mathrm{SME}_{\mathrm{S}}\right) . \mathrm{SME}_{\mathrm{S}}$ accounting for $92 \%$ of businesses in Ghana capturing over $60 \%$ of labor force hence contributing $22 \%$ to the Gross Domestic Product (GDP). These statistics projects $\mathrm{SME}_{\mathrm{S}}$ as the most important sector in the Ghanaian economy. Not undervaluing their imperative role in economic development, SMEs create opportunities for the generation and distribution of income, poverty reduction by creating job opportunities as well as empowering women to engage in various businesses [7]. However, less attention has been paid in motivating SMEs to comply to taxes. [3] postulated that a 
major challenge confronting the Ghanaian government is that although there are a couple of donor supports in Ghana Revenue Authority (GRA) projects, there has been little support in encouraging SMEs to comply with taxes. This has therefore gone a long way into creating debates towards the issue of SME taxation. This paper therefore seeks to bring the attention of the GRA reasons hindering SMEs compliance to taxes.

\section{Literature Review}

\subsection{Overview of Domestic Taxes in Ghana (Source: Ghana Revenue Authority)}

\section{Domestic Taxes}

These kinds of taxes are managed by the Domestic Tax Revenue Division (DTRD) of the GRA. The merging of Value Added Tax (VAT) and the Internal Revenue Service (IRS) brought the idea of domestic taxation. Domestic taxes currently administered in Ghana comprises:

Income Taxes. Income taxes is an embodiment of Pay as You Earn Tax (PAYE), Corporate Tax and Personal Income Tax. Corporate tax constitutes taxes that are paid on companies profit at the end of an accounting year. The tax rate is $25 \%$. Personal Income Tax is associated to the payment of taxes by self-employed individuals. Lastly, the deduction of taxes by formal or salaried workers in order to satisfy their income tax obligations is also known as PAYE taxes.

Tax Stamp: This taxes are collected on quarterly basis. They are accrued from various self-employed business persons in the informal sector. Tax stamps groups businesses into it appropriate classes and sizes in order to charge equitable or fair tax rate on their business operations according to such groupings.

Stamp Duty: Stamp duty taxes are taxes documents that possesses legal effect. These taxes were administered under the Stamp Duty Act, 2005 (Act 689).

Gift Tax: This is a 5\% tax paid on the total face value taxable gifts in a year of assessment. Examples of this gifts subjected to taxes are land, foreign currency, shares, bonds and securities and business assets.

Capital Gains Tax: Capital Gain Taxes are 15\% tax paid on the sale of chargeable assets with gains surpassing GH\$50.00. Assets subjected to taxes with Capital Gains Tax includes; land and buildings, goodwill and company shares.

Rent Tax. This is an $8 \%$ tax paid by rent income earners on their gross rent income in a year of assessment.

Mineral Royalties. This is a $5 \%$ tax levied on the extraction of natural resources in Ghana.

Communications Service Tax (CST): The Communications Service Tax (CST) is a tax imposed on consumers for the usage of communication services by communication service providers. The communication service providers pay the taxes accrued from it consumers on a monthly basis.

Value Added Tax (VAT): This is a 15\% tax levied on consumers' expenditures through the purchases of goods and services. Business operators accumulates 
these taxes accrued from consumers and accounts for them to the GRA on a monthly basis.

National Health Insurance Levy (NHIL): This is a levy on all goods and services imported or supplied in the country unless otherwise exempted. A rate of $21 / 2 \%$ is charged on the selling price of goods supplied or service rendered.

VAT Flat Rate Scheme (VFRS): VFRS is solely designed for traders in the retail sector. Under the VFRS, registered retailers are expected to charge a 3\% marginal rate on the value of each taxable item sold.

\subsection{Tax Compliance and the Growth of SMEs}

Resources SMEs direct towards the payment of taxes can be used as reinvestment in facilitating future growth of their businesses [8]. With respect to calculations, it is evident that the reduction in compliance and tax rate upsurges the profit margin of SMEs thereby increasing government revenue by reducing the shadow economy [9]. The imperious regulatory environment in combination with the plethora regulatory agencies exert serious burden on the daily operational activities of SME owners thus hindering the growth of their businesses. These complexities in regulatory systems poses a distortionary effect on the growth of SME businesses. Such complexities in regulatory systems gives SMEs extra zeal to evade taxes as they are expected to morph into forms offering lower or no tax burden at all [10]. An improperly executed tax system also leads to reduction in efficiency, rise in collection charges, waste of time for taxpayers and the staff, low accrued taxes, and the distortion of optimal resource allocations [11]. These charges affect SMEs negatively because the compliance cost of SMEs is higher than other companies when scaled by sales or assets [12].

\subsection{Tax Policy Measures Favorable to SMEs Growth}

The improvement in the financial and investment climate in Ghana is essential in encouraging tax compliance because some SMEs functions in the shadow economy are of the view that the tax regulations enacted is hostile to their development. SMEs operating in the shadow economy constitute untapped revenue potential and are supposed to be captured by the Ghanaian tax net base [13]. Tax policies are efficient to SMEs growth if tax rates are may not necessarily affect their development. Tax burden should be lighter on the indigent people as well as the intensity in the fight against corruption and tax evasion [14]. Tax policies can be designed not only to negatively affect the growth of SMEs businesses but to circuitously shove their growth. In China, a tax policy has been enacted to encourage the financing of SME business through the exemption of business taxes to financial institutions that grants loans to SMEs [7]. Also, the awareness of the dangers of noncompliant behaviors by SMEs have grown therefore, designing tax policies that encourage human capital training will encourage compliance decisions of most SME businesses [15]. Furthermore, government can employ policy incentives such as tax rebates aiming to lay effort on local sourcing of raw materials as well as adding value to commodities for ex- 
ports.

\section{Research Methodology}

\subsection{Research Hypothesis and Theory}

\subsubsection{SMEs Perception on Taxes}

According to [7] in their concluding remarks indicated that most SMEs see taxes as a way of undermining their growth thereby possessing a stinking graft perception on tax policies. Ghanaian taxpayers see taxes as a government strategy to lure money away from taxpayers without using them for their intended purposes. Most taxpayers are of the view that tax officials and tax administrators embezzles the money paid to them as taxes. Based on this, most taxpayers including SMEs have a negative perception towards taxes and intends not to pay taxes at all. In buttressing this point, [16] posited that players in the SME sector see taxes as just government way of earning revenue with no much good to the SME's and the society at large. Irrespective of SMEs ill feelings towards taxation in general, [17] postulated that the three key situations affecting SMES owners' perception on tax policies are: meaningful tax knowledge; decisions that portrays taxes as a painful loss; perception about non-compliance opportunities. Based on the above literatures reviewed, we derive our first hypothesis as:

$\mathrm{H}_{1}$ : $\mathrm{SME}_{\mathrm{S}}$ have bad perceptionson taxes in Ghana.

\subsubsection{SMEs Perception and Tax Compliance}

Tax compliance in simple terms is fulfilling all tax obligations freely and completely [18]. Most Ghanaian SME owners are of the view that high compliance cost levied against SMEs is a way of diminishing SMEs competitiveness against the big firms in the country. SMEs perception on taxation in Ghana is not quite appealing. Most SME owners sees taxation as unfair and corrupt thereby encouraging noncompliant behaviors [7]. It is widely viewed that SMEs perception on tax compliance may not arise from the imposition of high tax rates but may hinge on their illiteracy rate [7]. Petty businesses in Ghana considers tax compliance as an attempt by governmental agencies to deter their growth [7]. SMEs perceive compliance to taxes as the payment of monies used by tax officials to cater for themselves and their families therefore posing a stinking graft on SMEs compliance decisions on taxes [19]. Based on the above literatures, we derive our second hypothesis as:

$\mathrm{H}_{2}$ : Taxpayers' perception on taxes negatively affects tax compliance.

\subsubsection{SMEs Growth Opinions and Tax Compliance}

Taxes retrieved from taxpayers are integral source of money in the development of a country. The eagerness of most government with developmental projects connotes the imposition of high tax rates which undermines the growth of SMEs in Ghana [7]. Although various SME owners enjoys some tax exemptions, those tax exemptions are perceived as a government strategy to impose high tax rates in areas in which there are no exemptions. Due to this, most SMEs ponders on the fact that virtually no tax exemptions are offered in helping the growth of 
their businesses. The dearth of tax exemptions hinders the expansion and internationalization of various SMEs in Ghana thereby affecting their compliance to taxes [7]. In Ghana, the regulatory systems of SMEs and large corporations are the same thereby forcing SMEs to perceive a sense of discrimination against larger companies on the count that the requirement of compliance, cost of compliance and rate of taxes are equal for both SMEs and larger corporations [7]. Such uneven nature of policies enacted can impede on the growth of SMEs. Based on the above literature, we derive our third hypothesis as:

$\mathrm{H}_{3}$ : SMEs growth opinions negatively affect tax compliance.

\subsection{Tax Compliance Theories}

The accurate theory in encouraging compliance to taxes is debatable. Some researchers are of the view that the superlative way in encouraging tax compliance is by increasing incentives given to taxpayers' whiles others believe imposing high penalty charges to taxpayers who evade taxes [20]. Tax compliance theories can be classified into two namely: deterrence based theories and psychology based theories. However, in this paper we shall be considering the ability to pay principle under the deterrence based theory in order to check for taxpayers' perception on how equitable tax systems are and how it also affect their compliance decisions.

\subsubsection{Psychology Theories}

Psychology theories focuses on taxpayers' morals and ethics. This theory postulates that a taxpayer may comply to taxes if the probability of detection is low. Psychology theory places much efforts on changing taxpayers' attitudes towards tax systems opposing the view that an increment in tax penalties and rigorous audit systems wouldn't encourage tax compliance.

\subsubsection{Deterrence Based Theory}

This theory perceives that taxpayers are influenced by economic motives such as the maximization of returns profit and probability of detection. These economic motives allow taxpayers to analyze the likelihood of being detected after and before evading taxes and the repercussions aligned to tax evasion, decision of whether or not to evade taxes etc. Taxpayers can therefore choose the best possible alternative that maximizes their expected after tax returns. The ability of the taxpayer in going through these alternatives is called "playing the audit lottery" by [21].

1) Ability-to-Pay Principle

This principle is viewed as the most equitable tax system and is being used in industrialized economics. Under the ability-to-pay principle, taxation should be levied according to taxpayers' ability to pay. This principle goes further to suggest that public expenditure should come from "him that hath" instead of "him that hath not". This theory forms the core basis of "progressive tax" because tax rate increases by the increase of the taxable amount. With this principle, taxpayers are deprived of the monies they would have used for their personal business- 
es because those monies are surrendered to the government. Equity of sacrifice by taxpayers can therefore be measured in absolute, proportional or marginal terms.

\subsection{Conceptual Framework}

The conceptual framework of this research (Figure 1) hinges on the above literatures reviewed on the hypothesis and the research theories adopted. The conceptual framework of this study proposes SMEs Growth Opinions and Perception as the two main independent variables having either a positive or negative effect on compliance to taxes.

\subsection{Research Design and Data Collection}

In evaluating the effects of SMEs growth opinions and perception on tax compliance, this research espoused the qualitative and quantitative research approach. Logical reasoning was also applied to reflect respondents' responses to ensure precision, result accuracy and objectivity in the data collected. Qualitative data was obtained through field notes and taped interviews. In analyzing the quantitative data, we employ a 5 point Likert scale ranging from completely disagree to completely agree with neutral scores amidst the two scores. Completely Disagree is denoted by 1 , Disagree is denoted by 2, Neutral is denoted by 3 , Agree is denoted by 4 and Completely Agree is also denoted by 5. Primary data was obtained using questionnaires containing individual judgement of the variables under each construct. The questionnaires consisted of two sections. The first section consisted of 8 items with the aim of attaining the biographic information of respondents and the second section comprises the seventeen (17) $\mathrm{Li}$ kert scale items of the variables under consideration. Questionnaires were submitted to 840 SMEs from the ten regions of Ghana. A total of 84 questionnaires was submitted to registered SME businesses in each of the ten regions in Ghana.

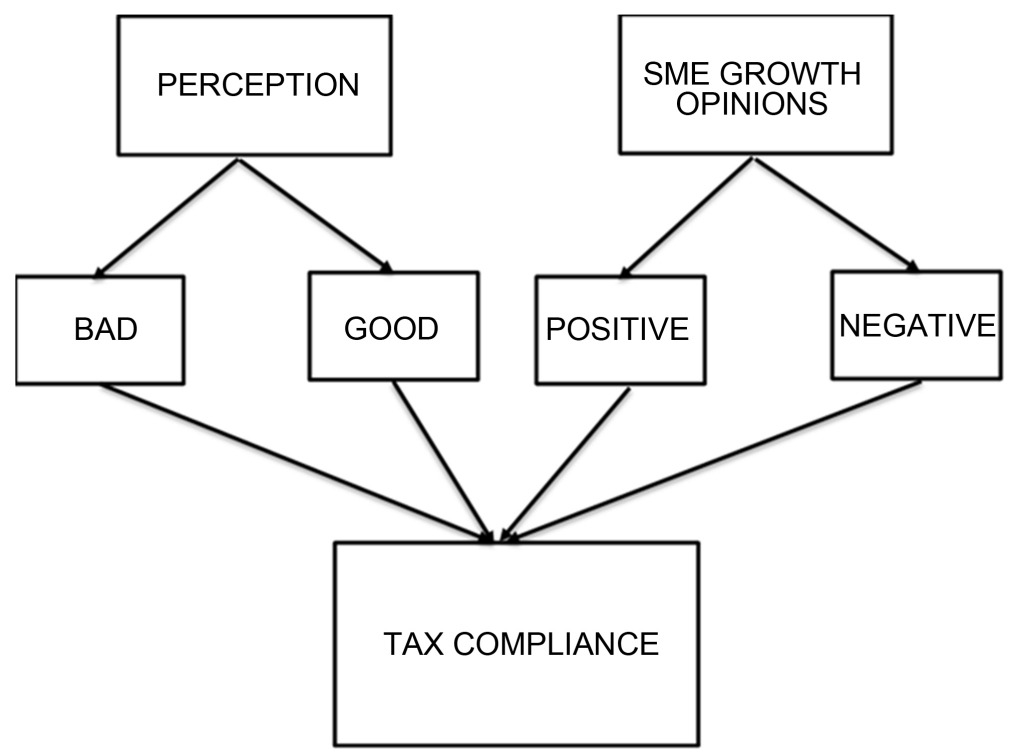

Figure 1. Conceptual framework; Source: authors own construct (2017). 
Respondents included various SME owners in the regional capitals of Ghana. Stata 12 and E-views 7.1 was employed in analyzing quantitative data obtained. Questioners retrieved from respondents were analyzed using descriptive statistics and regression analysis. Reliability and validity test was also undertaken to obtain the strength of each construct.

\section{Research Analysis Presentation}

\subsection{Descriptive Analysis}

Out of the 840 questionnaires submitted, 752 constituting $89.52 \%$ was retrieved. The 752 retrieved questionnaires constituted 452 (60.1\%) females and 300 (39.9\%) males. With respect to age, 440 (58.5\%) fell within the age range of 30 and below, $212(28.2 \%)$ were within the range of 31 to 45 whereas 100 (13.3\%) also fell within the age range of 46 and above. 84 questioners were submitted to respondents of each regional capitals of Ghana with 76 (90.5\%) retrieved from Accra (Greater Accra Region), 74 (88.1\%) from Koforidua (Eastern Region), 79 (94\%) from Takoradi (Western Region), 79 (94\%) from Kumasi (Ashanti Region), 74 (88.1\%) from Cape Coast (Central Region), 74 (88.1\%) from Ho (Volta Region), 74 (88.1\%) from Sunyani (Brong Ahafo Region), 76 (90.5\%) from Tamale (Northern Region), 71 (84.5\%) from Bolgatanga (Upper East Region) and 75 (89.2\%) Wa (Upper West Region).

With reference to the overall mean figure of 4.29 obtained from Table 1, it is evident that overall respondents' have a bad perception towards taxes indicating that respondents' responses are in consonance to the first hypothesis drawn that SMEs have bad perception on taxes in Ghana.

Table 2 depicts an overall mean figure of 4.27 indicating that SMEs rarely fulfill their tax obligations.

With respect to the overall mean of 4.82 obtained (Table 3 ), it is evident that

Table 1. SMEs perception on taxation.

\begin{tabular}{|c|c|c|}
\hline \multirow[t]{2}{*}{ VARIABLES } & \multicolumn{2}{|c|}{ PERCEPTION } \\
\hline & Count Mean & $\begin{array}{l}\text { Standard } \\
\text { Deviations }\end{array}$ \\
\hline $\begin{array}{l}\text { Taxes serve as good sources of income to the } \\
\text { government but aren't used for their intended purposes. }\end{array}$ & 3.04 & 1.10 \\
\hline $\begin{array}{l}\text { Taxes is just a way of government earning revenue with } \\
\text { no much good to the SMEs }\end{array}$ & 4.72 & 1.01 \\
\hline Taxes are painful loses to SMEs. & 4.84 & 0.84 \\
\hline Taxes are complicated. & 3.21 & 1.02 \\
\hline Tax rate is set too high & 4.64 & 0.83 \\
\hline Tax is unfair to SMEs. & 4.76 & 1.21 \\
\hline $\begin{array}{l}\text { SMEs hardly achieves its expected profit and therefore } \\
\text { sees income taxes as just an extra loss to the firm }\end{array}$ & 4.82 & 1.25 \\
\hline Overall & 4.29 & 1.02 \\
\hline
\end{tabular}

Source: Authors field survey. 
Table 2. Descriptive measures on compliance to taxes.

\begin{tabular}{ccc}
\hline VARIABLES & \multicolumn{2}{c}{ COMPLIANCE } \\
\hline & Count Mean & Standard Deviations \\
\hline Tax duties are fulfilled once in a while & 4.01 & 1.04 \\
The enterprise forcefully pays taxes & 4.84 & 1.40 \\
The enterprise never pays tax & 4.51 & 1.23 \\
The enterprise does not consider the amount of & 4.15 & 1.14 \\
taxes to be paid in its monthly accounts & & 0.72 \\
I do not pay a penalty if I don't fulfill my & 3.84 & $\mathbf{1 . 1 1}$ \\
Personal income tax duties & & \\
Overall & 4.27 &
\end{tabular}

Source: Authors field survey.

Table 3. SMEs growth opinions.

\begin{tabular}{|c|c|c|}
\hline \multirow[t]{2}{*}{ VARIABLES } & \multicolumn{2}{|c|}{ GROWTH } \\
\hline & Count Mean & Standard Deviations \\
\hline $\begin{array}{c}\text { The payment of taxes has caused a reduction in } \\
\text { the cash at hand of the enterprise }\end{array}$ & 4.98 & 0.82 \\
\hline $\begin{array}{l}\text { Non-compliance to taxes has helped in the } \\
\text { growth of the enterprise }\end{array}$ & 4.94 & 0.80 \\
\hline $\begin{array}{l}\text { I can firmly say that the payment of taxes } \\
\text { impedes on the growth of businesses }\end{array}$ & 4.71 & 0.89 \\
\hline $\begin{array}{l}\text { Payment of taxes affects the daily operations of } \\
\text { our businesses }\end{array}$ & 4.67 & 0.69 \\
\hline Overall & 4.82 & 0.80 \\
\hline
\end{tabular}

Source: Authors field survey.

respondents' subjective opinions on growth depicts that SME owners realizes a negative growth opinions on the effect on taxes on their businesses.

Table 4 depicts an average respondents' responses to SMEs growth opinions, perception and tax compliance. Of all the constructs, the average mean of more than 4 indicates that respondents agree to each of the questions posed under each of the variables that their subjective growth opinions and their perception on taxes have a negative effect on tax compliance.

Table 5 represents validity and reliability scores of the variables. Under discriminant validity, the correlation of different construct shouldn't be highly correlated but values obtained after cross loading indicates higher values for each indicator thereby opposing the assertion of discriminant validity thereby depicting the validity of the instruments used in this research. Convergent validity tests that constructs that are expected to be related are, in fact, related. Under 
Table 4. Summary statistics of variables.

\begin{tabular}{ccccccc}
\hline Variable & $\mathrm{N}$ & Def. & Min & Max & $\begin{array}{c}\text { Avg. } \\
\text { Mean }\end{array}$ & Avg. std.dev \\
\hline C & 752 & $\begin{array}{c}\text { SMEs Compliance to } \\
\text { taxes }\end{array}$ & 3 & 5 & 4.27 & 1.11 \\
P & 752 & $\begin{array}{c}\text { SMEs Perception on } \\
\text { taxes }\end{array}$ & 2 & 5 & 4.29 & 1.02 \\
G & 752 & $\begin{array}{c}\text { SMEs subjective Growth } \\
\text { opinions }\end{array}$ & 3 & 5 & 4.82 & 0.80 \\
\hline
\end{tabular}

Source: Authors field survey.

Table 5. Reliability and validity test.

\begin{tabular}{cccc}
\hline \multirow{2}{*}{ Variables } & \begin{tabular}{c} 
Results \\
Composite \\
\cline { 2 - 3 }
\end{tabular} & Cronbach Alpha & AVE \& Communality \\
Perception & 0.9461 & 0.9316 & 0.7431 \\
Growth & 0.9127 & 0.9016 & 0.7567 \\
Compliance & 0.932 & 0.9227 & 0.7328 \\
\hline
\end{tabular}

Source: Authors field survey.

convergent validity, an indicator can't be deleted when the values of the loading variables are amid 0.50 and 0.70 . From Table 5, the values of the Communality and Average Variance Extracted (AVE) are above 0.50. It can be concluded from Table 5 that the outer loading factor values of the constructs are greater than 0.70 and the communality and AVE values are also greater than 0.50 . This depicts that the instruments used in this research analysis is valid and reliable.

\subsection{Formulation of Regression Equation}

The regression equation formulated in this research is:

$$
C=A+\beta 1 P+\beta 2 G+\varepsilon
$$

where; $C$ represents Tax Compliance of SMEs

$A$ represents the constant

$P$ represents Perception of Tax Policies of SMEs

$G$ represents Tax impact of SMEs growth in the opinion of SME owner and $\varepsilon$ represents the error term.

\subsubsection{Regression Analysis}

In order to know the relationship that exists between SMEs growth opinions and their perception as well as their compliance to taxes a regression analysis was conducted. In coming out with the regression results, the dependent and independent variables under consideration were observed where "Tax Compliance" is the dependent variable whiles "SMEs perception" and "growth opinions" of SMEs are the independent variables in this study. The core objective of this study is to identify the factors that affect SMEs compliance to taxes. Before this 
core objective can be achieved, it is important to find out whether SMEs perception on taxes negatively affect compliance to taxes and how SMEs subjective growth opinions also affect tax compliance. To achieve this aim, it is therefore prudent to run a regression analysis on the data obtained from the variables under consideration.

From Table 6, it could be observed that the $\mathrm{R}$ square of 0.718 shows that the predictors are able to explain $71.8 \%$ of the dependent variable. All the " $\mathrm{B}$ " values and "Beta" values are positive indicating a direct relationship between the predictors (Perception and Growth) and the dependent variable (compliance). However, the most influential predictor in this context is Growth with the highest coefficient $[\mathrm{B}=0.714,(\mathrm{P}=0.000)]$. It can therefore be said that growth opinions of SMEs have a high influence on their level of compliance to taxes. The regression equation therefore becomes: $\mathrm{C}=0.071+0.453 \mathrm{P}+0.714 \mathrm{G}$. From the regression equation derived, it can be mathematically concluded that if Growth is fixed, then for each change of 1 unit in Perception, Compliance changes 0.453 units. Also, if Perception is fixed, then for each change of 1 unit in Growth, Compliance changes 0.714 units.

\section{Discussion}

Compliance to taxes is a challenge for both the Ghana Revenue Authority and the government as a whole. The Government of Ghana with the Ghana Revenue Authority is putting in appropriate measures to increase the level of tax compliance and effectiveness by organizing awareness campaigns and media announcements but despite the high monetary injection on policies and technology to aid in taxpayers' compliance, their efforts seemed futile over the years. Taxation play a crucial role in the profitability and survival of most businesses in Ghana. Policies enacted concerning taxes should be strategically and meticulously instituted in order to surge the number of taxpayers' and in particular, SMEs compliance notwithstanding its potential effects on their growth. In an ideal situation, taxpayers wouldn't hesitate to pay taxes but the institution of certain policies renders the contraction of their businesses. Growth of SME businesses has an impact on tax compliance. SMEs argue that they will always trade the payment of taxes to protect the growth of their businesses. Ideally,

Table 6. Regression analysis dependent variable: compliance.

\begin{tabular}{cccccc}
\hline \multirow{2}{*}{ Model } & \multicolumn{2}{c}{ Unstandardized coefficients } & $\begin{array}{c}\text { Standardized } \\
\text { coefficients beta }\end{array}$ & T & Sig. \\
\cline { 2 - 3 } & B & Std. error & 1.141 & -0.204 & 0.314 \\
(Constant) & 0.071 & 0.112 & 0.448 & 0.324 & 0.001 \\
Perception & 0.453 & 0.216 & 0.693 & 0.482 & 0.000 \\
Growth & 0.714 & Adjusted R Square & & \\
R & R Square & \multicolumn{2}{c}{0.704} \\
0.726 & 0.718 & \multicolumn{2}{c}{} \\
\hline
\end{tabular}

Source: Authors field survey; significance at 0.05 level. 
most citizens will side with this notion because the existence of their businesses corresponds to the survival of their family thus improving their standard of living. SMEs seem to be very emotional when tax policies are instituted to affect their growth. Based on this, most SME owners go the extra mile to dodge the payment of taxes without thinking of the penalties inflicted on them for dodging taxes. Based on taxpayers' responses, it was realized that SMEs negative subjective opinions on the growth of their businesses affect their compliance to taxes. SMEs argue that most tax officials do not know the daily operational expenses they incur in the day to the day operations of their business and that any evidence of contraction in their businesses will affect their compliance to taxes. They further argue that although taxes serve as revenue to the government, they would rather protect their business first before that of the nation at large. In Ghana, taxpayers' perception on taxation seems dwindling as each day passes by. Most taxpayers are of the view that policies enacted by parliament on tax issues heaps a huge burden on the profitability of their business thereby affecting the understanding of most tax policies passed by law. With reference to our findings, taxpayers overall count mean value of 4.29 on perception agrees to the fact that there is a bad perception on tax policies instituted because taxpayers believe that personal income tax rates are high thereby allowing government to earn high revenues with no good to SMEs. During the survey, we had the chance to speak to some tax officials and it was realized that the level of education and enlightenment on taxation seems to be different with regards to both tax officials and taxpayers. The reason for the huge gap with respect to perception for both taxpayers and tax officials stems from the fact that most SME owners are illiterates and that they perceive taxes as a mere negative effort that impedes on the growth of their business. The findings of this research piece go a long way in agreeing to the finding of [22] that SMEs have perception about non-compliance opportunity, decision-frame rendering taxes as painful losses and knowledge about tax-system which negatively affect their compliance to tax laws.

\section{Conclusion and Recommendation}

SMEs at most times have no assurance or realization that the policies enacted or instituted by the parliament will positively affect the growth of their business. Without this assurance, SMEs seems to have a negative view on the tax policies enacted. SME owners are of the view that the payment of taxes puts the profitability of their businesses in danger and poses a threat to their daily operational activities. The study was piloted to depict the effects of SMEs subjective growth opinions and perception on tax compliance. The three objectives derived to arrive at an accurate conclusion proved significant. From the hypothesis, all the predictor variables from the hypothesis satisfy the regression model: $\mathrm{C}=0.071+$ $0.453 \mathrm{P}+0.714 \mathrm{G}$.

Based on the conclusions drawn, the following recommendations are proposed in order to positively improve the daily operations of SMEs as well as increasing their tax compliance to an appreciable level. SMEs should be educated 
on tax regulatory systems. Tax regulatory systems should be explained by erudite personnel to encourage SMEs understanding on tax systems. Also, appropriate technology should be introduced in the filing and payment of taxes to ease the cumbersome process one needs to go through in the payment of taxes. Furthermore, taxes collected by tax officials should be used for their intended purposes. Tax officials should also conduct their duties diligently and efficiently in order to eradicate corruption in tax administration. Finally, tax policies should be continually reviewed in relation to current economic situations in order to understand SMEs tax burden within different economic situations.

\section{Limitations of the Study}

This study focused on SMEs in regional capitals in all the ten regions in Ghana but ideally reaching out to various SME owners in the remote areas in Ghana would have brought attention to certain challenges SMEs faces which might not have been captured in this research piece. Also, regional comparisons on the challenges SMEs faces is also worth exploring. Finally, it will be vital to make a comparison analysis on how perception and subjective growth opinions on tax compliance with respect to taxpayers and tax officials perspective.

\section{Acknowledgements}

We are grateful to Joy Korang Agyeman and Mrs. Faustina Oware Korangteng for giving us support throughout this research work.

\section{References}

[1] Ojeka, S.A. (2011) Tax Policy and the Growth of SMEs. Implications for the Nigerian Economy. Research Journal of Finance and Accounting, 2. www.iiste.org/Journals/index.php/RJFA/article/download/182/66

[2] The World Bank Group (2011) China's Economic Restructuring and the Business Environment for US Companies in China. www.doingbusiness.org/data/exploreeconomies/china

[3] Dzadzra, A. (2011) SME Taxation in Ghana. Tax Policy Unit, Ministry of Finance and Economic Planning, International Tax Compact Conference, Bonn, Germany.

[4] IFC (2010) Scaling-Up SME Access to Financial Services in the Developing World, $1-144$.

[5] OECD Factbook Statistics (2010) DOI:10.1787/factbook-2010-en. www.oecd-ilibrary.org/economics/oecd-factbook-2010_factbook-2010-en https://doi.org/10.1787/factbook-2010-en

[6] Ghana Statistical Service (2012) 2010 Population and Housing Census. 1-117.

[7] Ameyaw, B., Korang, J., Twum, E. and Asante, I. (2016) Tax Policy, SMEs Compliance, Perception and Growth Relationship in Ghana: An Empirical Analysis. British Journal of Economics, Management \& Trade, 11, 1-11. https://doi.org/10.9734/BJEMT/2016/22030

[8] Tomlin, B. (2008) Clearing Hurdles: Key Reforms to Make Small Businesses More Successful. (Commentary No. 264). Toronto, Ontario C.D. Howe Institute. https://ideas.repec.org/a/cdh/commen/264.html

[9] Vasak, S. (2008) Small, Medium, and Large Enterprises. USAID Business Climate 
Reform. http://pdf.usaid.gov/pdf_docs/PNADQ675.pdf

[10] Masato, A. (2009) Globalization of Production and the Competitiveness of Small and MediumSized Enterprises in Asia and the Pacific: Trends and Prospects. Publication of United Nations Economic and Social Commission for Asia and the Pacific (ESCAP), Studies inTrade and Investment Series Chapter 1, 1-31.

[11] Farzbod, J. (2000) Investigation of the Effective Factors in the Tax Efficiency. Unpublished Master's Thesis, Governmental Management Training Center, Tehran.

[12] Weichenrieder, A.J. (2007) Survey on the Taxation of Small and Medium-Sized Enterprises: Draft Report on Responses to the Questionnaire. Retrieved from Organization for Economic Cooperation and Development. http://www.oecd.org/dataoecd/52/25/39597756.pdf

[13] International Tax Dialogue (2007) Taxation of Small and Medium Enterprises. Background paper for the International Tax Dialogue Conference, Buenos Aires.

[14] Shahrodi, S.M.M. (2010) Investigation of the Effective Factors in the Efficiency of Tax System. Journal of Accounting and Taxation, 2, 42-45.

[15] Yaobin, S. (2007) Tax, Small Business, Growth: Effect of Taxation on Investment and Crossborder Trade. Paper presented at the ITD Conference on Taxation of SMEs.

[16] Mwangi, M. and Nganga, I. (2006) Taxation and SME's Sector Growth. Asian Journal of Business and Management Sciences, 2, 1-7.

[17] Oludele, A.A. and Emilie, C.K. (2012) Regulation, Awareness, Compliance and SME Performance in Cameroon's Manufacturing and Retail Sectors. International Journal of Social Economics, 39, 933-950.

[18] Marti, L.O. (2010) Taxpayers' Attitudes and Tax Compliance Behavior in Kenya. African Journal of Business \& Management, 1, 112-122.

[19] Pope, J. and Abdul-Jabbar, H. (2008) Tax Compliance Costs of Small and Medium Enterprises in Malaysia: Policy Implications.

[20] Feld, L.P. and Frey, B.S. (2007) Tax Compliance as the Result of a Psychological Tax Contract: The Role of Incentives and Responsive Regulation. Law and Policy, 29, 102-120. https://doi.org/10.1111/j.1467-9930.2007.00248.x

[21] Trivedi, V.U., Shehata, M. and Mestelman, S. (2005) Attitudes, Incentives and Tax Compliance. Canadian Tax Journal, 53, 29-61. http://socserv.socsci.mcmaster.ca/ mceel/papers/taxcomp.pdf

[22] Mungaya, M., Mbwambo, A.H. and Tripathi, S.K. (2012) Study of Tax System Impact on the Growth of Small and Medium Enterprises (SMEs): With Reference to Shinyanga Municipality, Tanzania. International Journal of Management \& Business Studies, 2, 99-104. 
Submit or recommend next manuscript to SCIRP and we will provide best service for you:

Accepting pre-submission inquiries through Email, Facebook, LinkedIn, Twitter, etc. A wide selection of journals (inclusive of 9 subjects, more than 200 journals)

Providing 24-hour high-quality service

User-friendly online submission system

Fair and swift peer-review system

Efficient typesetting and proofreading procedure

Display of the result of downloads and visits, as well as the number of cited articles Maximum dissemination of your research work

Submit your manuscript at: http://papersubmission.scirp.org/

Or contact ojbm@scirp.org 